\title{
Biomarkører i rusmiddelfeltet
}

\author{
Jørg Mørland \\ Divisjon for rettstoksikologi og rusmiddelforskning, Nasjonalt folkehelseinstitutt, Postboks 4404 Nydalen, 0403 Oslo \\ E-post: jorg.morland@fhi.no Telefon: 23407801
}

\begin{abstract}
SAMMENDRAG
Biomarkørene som brukes i rusmiddelfeltet kan deles i tre hovedtyper: 1. Virkningsmarkører, 2. Inntaksmarkører og 3. Disposisjonsmarkører. Den siste gruppen omtales også som "trait-markers" og har så langt funnet liten anvendelse i Norge. Virkningsmarkører benyttes så langt for alkohol og uttrykker en biologisk virkning av alkoholkonsumet. De tre viktigste er MCV, GGT og CDT. Ingen av disse er spesifikke for alkoholinntak. MCV er minst sensitiv for alkoholinntak, mens CDT er mest sensistiv, men alle tre markørene fremviser betydelig individuell variasjon mht. respons på konsum. En endret verdi vil vedvare lengst for $\mathrm{MCV}$, kortest for CDT etter totalavhold. Inntaksmarkører utgjøres av påvisningen av et rusmiddel eller dets metabolitter i en biofase, særlig blod, saliva, urin eller hår. Uomdannet alkohol måles lett i de tre første av disse biofasene, med kort tidsvindu etter inntak. Alkoholmetabolitter som acetaldehyd-konjugat, FAEE og etylglucuronid kan måles i flere biofaser, med lengre, til dels betydelig lengre tidsvindu enn alkohol. Målingene er spesifikke, ofte sensitive, men det kvantitative aspekt er lite utredet. Andre rusmidler enn alkohol kan måles særlig i blod og saliva med relativt kort tidsvindu etter inntak. Rusmiddelmetabolitter påvises lettest $\mathrm{i}$ urin, men vil også finnes i blod, saliva og hår. Tidsvinduene for påvisning $\mathrm{i}$ urin og særlig hår kan ha betydelig lengde. Påvisningen er spesifikk så sant spesifikk analysemetode benyttes, sensitiviteten vil også være metodeavhengig. Resultatene av samtlige biomarkøranalyser krever høy faglig kompetanse for korrekt tolkning.
\end{abstract}

Mørland J. Biomarkers for alcohol and drug use. Nor J Epidemiol 2006; 16 (1): 7-13.

\section{ENGLISH SUMMARY}

Biomarkers for alcohol and drug use fall into three different categories: 1. Effect markers, 2. Intake markers and 3. Trait markers. The last group has so far not beeen used to any extent in Norway. In epidemiologic studies the two first markers are both considered to be state markers. Effect markers are used mainly to monitor alcohol intake by expressing a biological effect caused by this intake. The three most important ones are MCV, GGT and CDT, and none are specific to alcohol use. MCV is less sensitive that the others, CDT is probably most sensitive, but all three show substantial interindividual variation. After cessation of use, MCV will maintain elevated longer, and CDT shorter than the other two. Intake markers are represented by the detection of a drug or its metabolites in any biophase, in particular blood, saliva, urine or hair. Unmetabolized ethanol can be measured in blood, saliva and urine with short detection periods after intake. Ethanol metabolites like acetaldehyde-protein conjugates, FAEE and ethylglucuronide can be detected in several biophases with much longer detection periods. Other drugs than alcohol can be detected unmetabolized in blood and saliva shortly after intake, while drug metabolites in particular are also detected in urine. Both parent drug and metabolites might be found in hair for long periods after intake. Depending on the analytical method used, the detection can be highly specific and sensitive. Any biomarker detection requires considerable scientific knowledge for correct interpretation.

\section{INNLEDNING}

Det er flere definisjoner av hva en biomarkør er. De kan spenne fra "a substance sometimes found in the blood, other body fluids, or tissues" til "a biochemical feature or substance that can be used to diagnose and monitor disease". Den første, videste definisjonen har størst relevans for rusmiddelfeltet.

Det finnes mange forskjellige biomarkører i bruk i rusmiddelfeltet. Disse kan deles i tre hovedtyper:

1. Virkningsmarkører

2. Inntaksmarkører

3. Disposisjonsmarkører
Disposisjonsmarkører har vært lite i bruk i Norge. De benyttes særlig innen alkoholfeltet. De er også kalt "trait-markers" og skal angi et individs predisposisjon for å utvikle alkoholavhengighet. Tanken bak dette er igjen at denne predisposisjonen er knyttet til visse gener eller genkombinasjoner hos det aktuelle individ. Slike gener antas å øke risikoen for at vedkommende lettere skal utvikle alkoholavhengighet ved eksposisjon for alkohol. Tilstedeværelsen av disse genene eller genkombinasjonene kan også måles f.eks. ved forekomsten av et eller flere genprodukter $i$ et biologisk vev, fortrinnsvis blod. Det drives betydelig forskning innen dette området $(1,2)$, men per i dag har man ikke 
kommet frem til entydige "trait-markers". Slike vil derfor ikke bli diskutert nærmere i denne oversiktsartikkelen. I det følgende vektlegges bruken av biomarkører som hjelpemidler til å kartlegge rusmiddelinntaket hos enkeltindivider $\mathrm{i}$ epidemiologiske undersøkelser av skade, sykdom og helse.

Virkningsmarkører representerer målbare endringer som kan oppstå i organismen som følge av rusmiddeleksposisjon. Det kan for eksempel dreie seg om påvisning av økt mengde av et protein som har lekket ut fra skadede celler til blodet. I slike tilfelle kan biomarkøren også anses som en skade- eller sykdomsmarkør. Andre ganger kan virkningen bestå $i$ at rusmiddelbruken endrer biokjemien $i$ organismen uten at det nødvendigvis foreligger sykdom eller skade. En slik endring vil kunne måles for eksempel i blodet ved at mengden av et spesielt protein endres eller at blodlegemene forandres. Innen rusmiddelfeltet er det først og fremst for alkoholbruk virkningsmarkørene har fătt anvendelse, slik som måling $\mathrm{i}$ blod av GGT, CDT og MVC.

Inntaksmarkører utgjøres av målinger av rusmiddelet selv eller dets omdannelsesprodukter i biologiske væsker, vev med mer, for eksempel blod, urin, spytt, hår, biopsier etc. Det kan diskuteres om måling av det uomdannede rusmiddelet, det være seg for eksempel alkohol eller amfetamin, tetrahydrocannabinol eller ecstasy, $i$ en biologisk væske eller et vev representerer en biomarkør. Kanskje skulle biomarkørbegrepet først benyttes når kroppens biokjemi hadde gjort noe med stoffet, metabolisert det, koblet det, eller bundet det til en kroppsegen komponent. Overgangen her er gradvis fra ren eksogen komponent, til et biokjemisk omdannelsesprodukt som alle vil anse som en biomarkør, for eksempel acetaldehyd dannet fra alkohol og deretter koblet til hemoglobin. For enkelthets skyld er målinger av uomdannet rusmiddel i en biofase omtalt som en biomarkør i denne artikkelen. For å kunne benytte potensialet ved slike markører fullt ut, kreves det betydelig innsikt i rusmidlenes farmakokinetikk.

\section{BIOMARKØRER OG EPIDEMIOLOGISKE UNDERSØKELSER}

I denne artikkelen har jeg valgt å diskutere biomarkører fra den synsvinkel at de representerer mål for rusmiddeleksposisjon. Ut fra definisjonen om at en biomarkør er en substans som kan brukes til å monitorere sykdom, vil rusmiddeleksposisjon da bli synonymt med sykdom. Det er det selvsagt ikke. Riktignok vil enkelte bruksmønstre av rusmidler kunne ses på som utslag av sykdom, hvis man mener rusmiddelavhengighet representerer en form for sykdom. Dette er imidlertid en vanskelig diskusjon som jeg ikke finner det hensiktsmessig å gå inn i her. For praktisk bruk i epidemiologiske undersøkelser kan det imidlertid ofte være behov for å ha markører for rusmiddeleksposisjonen. De vil i så måte supplere de opplysninger man får inn om bruk av rusmidler ved intervju eller spørre- skjema. Mht. effektene av rusmiddelbruk vil de stort sett fanges opp ved måling av forskjellige endepunkt i de epidemiologiske undersøkelsene, som for eksempel registrering av forskjellige sykdommer, forstadier til sykdom, endringer $\mathrm{i}$ risikofaktorer knyttet til forskjellige sykdommer etc. Dette kunne tilsi at visse virkningsmarkører knyttet til for eksempel celleskade (ASAT, ALAT) eller endringer i markører som også representerer risikofaktorer (HDL-kolestrol), kunne ses på som surrogatendepunkter. For å begrense temaet har jeg i det videre først og fremst betraktet biomarkører innen rusmiddelfeltet som eksposisjonsmarkører. Dette innebærer at bruken av biomarkører må ses på som et mulig supplement til andre opplysninger om rusmiddelbruk. Da slike opplysninger er notorisk usikre pga. enkeltpersoners manglende evne eller vilje til detaljert nok å huske rusmiddelinntakene og deres størrelse, kan biomarkører for eksposisjon være svært viktige. Om de alltid gir et riktigere bilde av eksposisjonen enn intervju og spørreskjemaopplysninger, er tema for videre diskusjon. I undersøkelser hvor rusmiddelspørsmål ikke er stilt, blir markørene den eneste kilde til å måle rusmiddeleksposisjonen.

Denne bruken av biomarkører som skal diskuteres her blir således noe forskjellig fra bruken av biomarkører i pasientbehandling, og mer opp mot det vi kjenner fra bruken av markører i klinisk screening. Fellestrekk vil imidlertid finnes mellom målinger i klinisk oppfølging og repeterte målinger av en biomarkører i rusmiddelundersøkelser for å følge inntaket over tid.

Den ideelle biomarkør i epidemiologisk sammenheng er den som måler rusmiddelbruken spesifikt for det aktuelle rusmiddel, dvs. det er kun bruk av det aktuelle rusmiddel som kan påvirke markøren. Den har videre kjent sensitivitet, dvs. man vet hvilken rusmiddeleksposisjon som skal til for å fremkalle en målbar endring i markøren. En ideell markør responderer videre gradert og den kvantitative endringen reflekterer den inntatte rusmiddelmengden. Den ideelle markør skal videre kunne fortelle noe om historikken til rusmiddelinntaket, dvs. om varigheten av rusmiddelbruken før målingen (tidsvinduet) og om evt. variasjoner i bruken i denne perioden. I epidemiologisk sammenheng kan det være en fordel om biomarkøren er stabil over en viss tid etter at rusmiddelinntaket har sluttet, og uansett er det viktig at halveringstiden av biomarkøren er kjent.

En rekke av de overnevnte krav til den ideelle markør er ikke kjent for dagens markører. For flere markører er det tvert i mot kjent at de ikke oppfyller de ideelle krav. Det kan likevel være hensiktsmessig å gjennomgå de mest brukte eksposisjonsmarkørene i rusmiddelfeltet i relasjon til de overnevnte krav.

\section{VIRKNINGSMARKØRER}

Det er kun for alkohol man har praktisk erfaring med måling av virkningsmarkører. Bruken av andre rusmidler enn alkohol har så langt ikke vært fulgt med virkningsmarkører. 


\section{Alkohol}

De tre mest brukte er, gjennomsnittlig volum av røde blodlegemer (MCV), gammaglutamyl transferase (GGT) og karbohydratfattig transferrin (CDT).

Andre markører som har vært brukt, men som reflekterer leverskade vel så mye som alkoholkonsum, er leverensymene aspartat aminotransferase (ASAT) og alanin aminotransferase (ALAT). Grovt sett vil disse markørene gi større utslag jo større skaden er, men noen klar sammenheng er ikke funnet. Oppfølging av markørene over tid, kan imidlertid si noe om sykdomsutviklingen (forverrelse/tilheling). Det synes å være stor individuell forskjell i utslaget på disse effektmarkørene, og også mht. andre biomarkører som reflekterer organskade. Det er så langt liten grunn til å tro at individer som er følsomme for effekter av kronisk alkoholkonsum i et organsystem, vil ha tilsvarende følsomhet $i$ andre organsystem. Som eksposisjonsmarkører for alkoholinntak er ASAT og ALAT lite egnet.

Nye biomarkører for alkoholeksposisjon er serum sialinsyre og forholdstallet mellom 5-hydroksytryptofol og 5-hydroksyindoleddiksyre (5-HTOL/5-HIAA). Serum sialinsyre (3) synes å reflektere virkninger av gjentatt alkoholkonsum av en viss varighet. Økningen i serum sialinsyre antas å skyldes virkninger av alkohol på sialinsyre-inkorporeringen i eller spaltingen fra karbohydratsidekjeder i glykoproteiner. Foreløpig er denne markøren ikke godt nok kartlagt som eksponeringsmarkør.

5-HTOL/5-HIAA (4) reflekterer endringer i sero- toninkatabolismen forårsaket av den endring i leverens reduksjons/oksydasjonsstatus som foreligger så lenge alkohol metaboliserer. Et enkelt alkoholinntak kan således avleses som en endring (økning) i 5-HTOL/5HIAA. Denne økningen måles i urin og kan foreligge opptil ett døgn etter at alkoholen har forsvunnet fra kroppen. Markøren har fått en viss anvendelse i kontroll av alkoholkonsum i behandlingsopplegg. Den kan også benyttes i epidemiologiske undersøkelser så sant det foreligger tilgang til jevnlige innhentede urinprøver.

En kort oppsummering for de tre mest brukte eksponeringsmarkørene er som følger:

\section{$M C V$}

Denne markøren måles som en klinisk biokjemisk rutineanalyse: Økninger i MCV er ikke spesifikke for alkoholinntak og kan forårsakes av flere forhold. Sensitiviteten for alkoholinntak er relativt lav og stordrikkere (heavy drinkers, med inntak over $60 \mathrm{~g}$ ren alkohol per døgn, dvs. for eksempel en snau flaske vin) viser bare en tendens til høyere resultater enn spredningen $i$ normalbefolkningen. Det antas å være betydelig forskjell mellom enkeltindivider mht. MCV-følsomhet for alkoholinntak.

I gjennomsnittet regner man at storkonsumet av alkohol må ha foregått i 8 uker eller mer før MCV vil gi utslag, se figur. Dersom MCV er forhøyet, kan den fortsette å være det 8-10 uker eller mer etter inntrådt totalavholdenhet. Dette kan henge sammen med at de blodlegemene som er blitt endret som følge av alkoholinntaket, vil fortsette å være så i hele sin levetid.

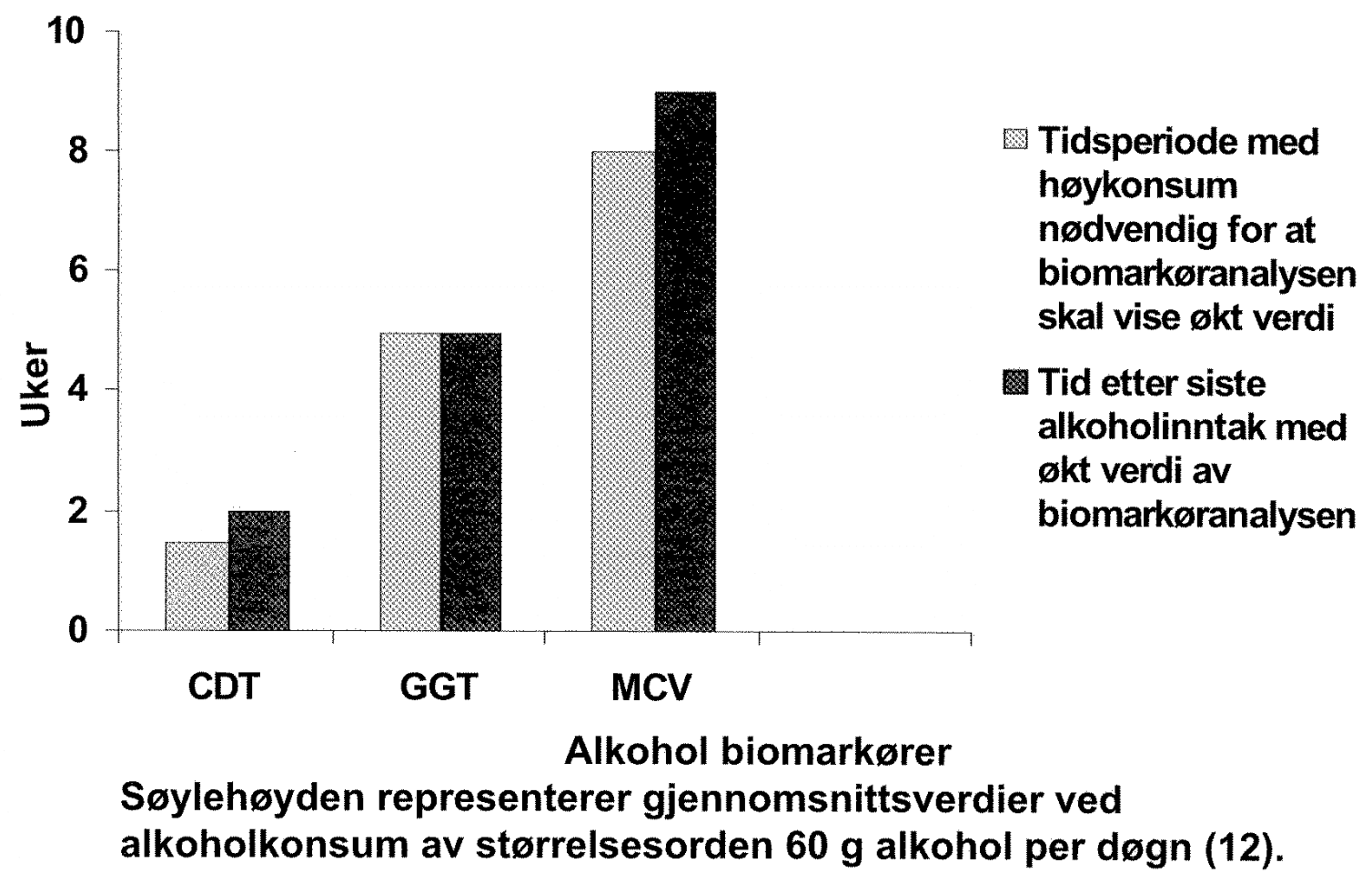




\section{$G G T$}

Endring (økning) av GGT kan måles i serum fra storkonsumenter av alkohol. Slike økninger er imidlertid ikke spesifikke for alkoholinntak. Økninger sees også ved leversykdom av flere årsaker, ved galleveislidelser, og etter bruk av flere forskjellige medikamentgrupper. De biokjemiske mekanismene som ligger bak GGT-økninger er ikke kjent i detalj. Alder, kjønn og BMI (body mass index) vil kunne påvirke GGT (5). GGT synes heller ikke å være spesielt følsom for alkoholinntakets størrelse. Bare 30-50 prosent av stordrikkere ( $>60$ g per dag) vil fremstå med økt GGT. Hos dem som viser utslag, vil GGT øke vanligvis først når storkonsumet har pågått 5 uker eller mer (se figur). Etter totalavhold vil en tilsvarende tid være nødvendig før GGT normaliseres.

\section{$C D T$}

Transferrin er et jernbindende sirkulerende glykoprotein. Det har flere karbohydrat-sidekjeder og normalt vil molekylet finnes i varianter med 4-5 sialinsyremolekyler per transferrinmolekyl. Storkonsum av alkohol synes å nedsette sialinsyre-inkorporeringen i sirkulerende transferrin og mengden av sialinsyre-fattig (og karbohydrat-fattig) transferrin vil øke. Analytisk kan dette måles ved flere forskjellige teknikker. Videre kan analyseresultatene angis som mengde av for eksempel summen av asialo, monosialo og disialo transferrin. Denne mengden kan uttrykkes i absolutte verdier, eller som prosent av alle isoformene av transferrin. Mekanismene bak økningen av de lavt sialiserte isoformene av transferrin som sees ved storkonsum av alkohol, er ikke kartlagt i detalj. Økningen av CDT ansees å være mer alkoholspesifikk enn økningen av GGT og MCV. Det kan ikke utelukkes at bruk av visse medikamenter kan øke CDT noe (6). Alder, kjønn og BMI kan påvirke CDT uavhengig av alkoholinntak (7). Kvinner har gjerne høyere CDT-nivåer enn menn. Sensitiviteten for alkoholkonsum synes å fremvise betydelig interindividuell variasjon, og noen stordrikkere vil følgelig ikke ha økt CDT. CDT vil vanligvis øke raskere ved storkonsum enn det som er tilfelle for MCV og GGT (se figur). Etter siste alkoholinntak vil det gjerne gå to uker før et forhøyet CDT-nivå vil normalisere seg.

\section{Kombinasjon av CDT og GGT}

Uspesifikk påvirkning av CDT og GGT, eller av disse biomarkørenes følsomhet for alkoholkonsum, har vist seg ofte å gå i motsatt retning for de to markørene, mens spesifikk påvirkning (alkohol) gir endringer $\mathrm{i}$ samme retning (økning). Dette har ført til at man har forsøkt om forskjellige kombinasjoner av CDT- og GGT-resultater kunne gi bedre informasjon om alkoholkonsumet enn det som var mulig ved bruk av biomarkørene hver for seg. Dette er fortsatt under utprøvning (8). Så langt synes det som kombinasjonen kan gi en viss tilleggseffekt for menn, men ikke for kvinner.

\section{INNTAKSMARKØRER}

Det finnes etter hvert stadig flere inntaksmarkører tilgjengelige for både alkohol og andre rusmidler enn alkohol.

\section{Alkohol}

Uomdannet alkohol

Den enkleste markøren for alkoholinntak er måling av alkoholkonsentrasjon i blod, spytt (saliva), utåndingsluft og urin. Alkohol er et lite molekyl som fordeler seg i kroppens vannfase, og det passerer relativt lett over biologiske membransystemer. Konsentrasjon av alkohol i vannfasen i blod, spytt og urin er tilnærmet den samme, når likevekt har inntrådt. Forholdstallet mellom alkoholkonsentrasjonen i blod og utåndingsluft viser en del variasjon. Alkoholkonsentrasjonen i blodet synker etter inntrådt likevekt med konstant hastighet, rundt 0,15 promille per time, $i$ alt vesentlig pga. levermetabolismen der acetaldehyd er første omdannelsesprodukt. Det er videre slik at alkoholkonsentrasjonen i spytt, luft og produsert urin blir 0 , når blodalkoholkonsentrasjonen blir 0. Blæreurin kan avhengig av tømming etter alkoholinntak, inneholde alkohol timer etter at blodalkoholkonsentrasjonen har sunket til 0. Alkoholkonsentrasjons målinger er spesifikke ved kromotografisk målemetoder. Bestemmelse av alkoholkonsentrasjoner i blod kan gi gode kvantitative opplysninger om det aktuelle alkoholinntak. Tidsvinduet kan være opp til 24 timer ved svære alkoholinntak.

\section{Alkoholmetabolitter}

Hovedmetabolitten til alkohol er acetaldehyd og praktisk talt all alkohol som inntas, vil omdannes til acetaldehyd. Denne omdannelsen skjer i leveren og på en måte som innebærer et nesten all acetaldehyd omdannes videre til acetat straks den blir produsert. Noe vil imidlertid alltid lekke ut til blodbanen, og noe av dette acetaldehydet vil igjen kunne binde seg til hemoglobin i de røde blodlegemene. På denne måten har man antatt at samlet konsum over en periode kan bli målt. Ved hjelp av "high-performance liquid chromatography" (HPLC) har man utviklet et målesystem for hemoglobin-assosiert acetaldehyd i fullblod (9). Dette har vært ansett som en brukbar markør for storkonsum av alkohol, men metoden kan ennå ikke sies å være godt nok evaluert.

En liten del av inntatt alkohol vil ikke metaboliseres til acetaldehyd, men danne esterforbindelser med forskjellige fettsyrer (FAEE; fatty acid ethyl esters). Slike kan påvises i serum opptil 24 timer etter avsluttet alkoholinntak. FAEE vil også finnes i hår, i måneder evt. lenger etter alkoholinntak av en viss størrelse. Målinger av FAEE i hår, blod og andre biologiske væsker er for tiden under nærmere utprøving og vurdering som biomarkører for alkoholkonsum. 
En lignende markør utgjør fosfatidyl etanol (PETH). Denne markøren har blitt påvist i fullblod mer enn to uker etter siste alkoholinntak (10) og er for tiden under videre testing.

En liten del av inntatt alkohol vil ikke metaboliseres via oksydasjon til acetaldehyd, men derimot konjugere (slik som tilfellet er for mange inntatte fremmedstoff) med glukuronsyre (ved hjelp av enzymsystemet uridin difosfat-glukuronyl transferase) eller med sulfat (ved hjelp av sulfotransferase-enzymer). Konjugatene etylglukuronid og etylsulfat kan påvises $i$ urinen opp til 5 døgn etter siste alkoholinntak. Påvisningen er metodologisk krevende og skjer ved hjelp av LC/MS evt. LC/MS-MS. Etylglukuronid er også påvist i hår, hvilket åpner muligheten for å ha en biomarkør som kan monitorere alkoholkonsum flere måneder, eller mer bakover i tiden. Etylglukuronid og etylsulfatmålinger er for tiden under evaluering i flere laboratorier rundt omkring i verden, men kan ennå ikke sies å ha funnet sin plass som biomarkør for alkoholkonsum.

Målinger av alkohol eller alkoholmetabolitter skiller seg fra virkningsmarkørene for alkohol ved at de alltid spesifikt viser et alkoholinntak. Sensiviteten bestemmes av målemetoden mht. hvor små kvantiteter som kan måles tilfredsstillende. Det er i stor grad ukjent så langt hvorvidt måling av de forskjellige alkoholmetabolitter i forskjellige medier kan gi informasjon om kvantiteten av alkoholinntaket. Gjentatte serielle målinger av uomdannet alkohol i blod eller enkeltinntak tillater inntaksbestemmelse, men tilgang på slike data vil sjelden foreligge i epidemiologiske studier. Noe uavhengig av alkoholmetabolittenes farmakokinetikk, kan man skaffe seg informasjon om alkoholinntak i perioden forut for måletidspunktet. Lagring $i$ hår (for de markører der dette er aktuelt) gir det største tidsvinduet bakover i tid.

\section{Andre rusmidler enn alkohol}

Kartlegging av bruk av andre rusmidler enn alkohol vil kunne bli stadig vanligere og viktigere $\mathrm{i}$ en rekke epidemiologiske undersøkelser. Fra spørreundersøkelser er det fremkommet opplysninger om at bruken av cannabis, sentralstimulerende midler og opioider (heroin og lignende stoffer) kan være relativt omfattende $\mathrm{i}$ deler av befolkningen. Inntaksbiomarkørene $\mathrm{i}$ denne sammenheng vil utgjøres av påvisningen av selve rusmiddelet $\mathrm{i}$ en biologisk væske e.l., eller ved at et omdannelsesprodukt av rusmiddelet påvises. Uomdannet rusmiddel er lettest å finne i blod og spytt (saliva), kort tid etter inntak. Rusmiddelmetabolitter vil ofte oppkonsentreres i urin og påvises lettest der, men slike metabolitter vil også finnes i blod, saliva og hår. Uomdannet rusmiddel vil også kunne påvises $\mathrm{i}$ urin og hår. I urin vil vanligvis metabolittene være til stede $\mathrm{i}$ langt høyere konsentrasjoner enn moderstoffet. I hår kan det være et problem at en del av det uomdannede rusmiddel som påvises, kan skyldes tilførsel fra røyk i rommet (heroin, cannabis, nikotin etc.), evt. være kontaminering fra fingre etc. Hårprøver må derfor gjennomgå en spesiell forbehandling før analyse av biomarkører settes i gang.

Så sant analysemetoden har tilstrekkelig spesifisitet, vil inntaket av rusmiddel kunne dokumenteres ved påvisning av rusmiddelet selv eller en metabolitt. De metodene som regnes som de mest spesifikke er gasskromatografi med massespektometrisk deteksjon (GC/MS) evt. væskekromatografi fulgt av massespektroskopi, helst med flere ioneoverganger (LC/MSMS). Ved bruk av slike metoder kan man med rimelig sikkerhet arbeide med spesifikke biomarkører for det stoff som er brukt. Andre, for eksempel de som er basert på immunologiske teknikker, vil ikke ha tilfredsstillende spesifisitet.

Anvendelsen og nytten av inntaksmarkører for andre rusmidler enn alkohol vil i stor utstrekning avhenge av hvilket medium man foretar biomarkøranalysen i. De fire viktigste biofasene er blod, saliva, urin og hår.

\section{Biomarkøranalyse i blod}

Et hvert rusmiddel vil absorberes til blodbanen fra inntaksveien (luftveiene, mage-tarmkanalen, gjennom huden osv.). Konsentrasjonen i blodet er høyest de nærmeste timer etter inntaket. Spesifikk bestemmelse av rusmiddelet i blod kan gi en grov indikasjon på inntakets størrelse når inntakstidspunktet(ene) er kjent. Blodkonsentrasjonen vil også etter at likevekt har inntrådt gi en indikasjon på konsentrasjonen i hjernen og andre organer og derfor en mulighet for å bedømme virkning(er). Måling av rusmiddelmetabolitter i blod kan utføres, og det vil særlig være i tilfelle der metabolittene er aktive og har lengre halveringstid enn moderstoffet, at dette kan gi tilleggsinformasjon. Eksempler på det siste er måling av morfin eller inntak av kodein, måling av morfin og morfin-6-glukuronid etter inntak av heroin, måling av meprobamat etter inntak av karisoprodol, måling av N-desmetyldiazepam etter inntak av diazepam, måling av etylkokain etter inntak av kokain og måling av amfetamin etter inntak av metamfetamin. Slike målinger av metabolitter sammen med moderstoff kan i noen tilfelle gi verdifull informasjon om inntakets størrelse. Målinger i blod gir vanligvis begrenset informasjon mht. hva som har foregått bakover i tid, da tidsvinduet for inntaksmarkørene i de fleste tilfeller kun er noen døgn etter inntak.

\section{Biomarkøranalyse i saliva}

Rusmidler og rusmiddelmetabolitter når frem til saliva ved diffusjonsprosesser og sekresjonsprosesser som frakter stoffene fra blod til spytt. Avhengig av stoffenes fysikalsk kjemiske egenskaper, kan pH i saliva påvirke fordelingen av rusmiddel og metabolitter mellom blod og saliva i vesentlig grad. Andre forhold som salivas sekresjonshastighet, kan være av betydning. Binding av stoffer til komponenter i saliva og grad av binding til proteiner i blod og blodlegemer vil også kunne påvirke fordelingen. Nylig inntak av rusmidler 
gjennom munnen kan gi kortvarige høye salivakonsentrasjoner.

Spesifikke metoder for målinger av uomdannet rusmiddel kan derfor vanskeligere enn for blod gi grunnlag for å anslå inntatt dose. Tidsvinduet for påvisning av moderstoff og metabolitter vil være omtrent det samme som for bruk av tilsvarende makører i blod.

\section{Biomarkører i urin}

Særlig rusmiddelmetabolitter vil utskilles og oppkonsentreres i urinen. Ved bruk av spesifikke metoder for enkeltmetabolitter er sensiviteten for deteksjon av de fleste rusmiddelinntak meget god. Noen god kvantitativ korrelasjon mellom rusmiddelinntakets størrelse og konsentrasjon av rusmiddelmetabolitt $i$ en enkelt prøve foreligger ikke, først og fremst pga. store konsentrasjonssvingninger i urinen i løpet av et døgn.

Påvisning av spesifikke rusmiddelmetabolitter i urinen kan spore rusmiddelinntak langt tilbake i tid, men med store individuelle variasjoner. Vanligvis vil inntaksbiomarkørene $\mathrm{i}$ urin for rusmiddelbruk ha et tidsvindu på 2-4 døgn, men for noen rusmidler kan tidsvinduet være betydelig lengre, flere uker for eksempel for påvisning av THC-syre etter siste cannabisbruk.

\section{Biomarkøranalyse $i$ hår}

Rusmidler og rusmiddelmetabolitter tilføres hår fra blodbanen til hårsekken på det voksende hår, men også via talg og svette til hårroten. Ved spesifikke biomarkøranalyser ønsker man først å fjerne rusmidler som kan ha festet seg til håret fra omgivelsene for eksempel fra røyk og kontaminerte fingre. For ytterligere å gardere seg mot kontaminering er det ønskelig at det påvises spesifikke rusmiddelmetabolitter. Ved hjelp av håranalyser kan man ha et sensitivt verktøy til å registrere rusmiddelbruk. Det kvantitative aspekt dvs. sammenhengen mellom mengder som måles $\mathrm{i}$ hår og de mengder som er brukt, er lite utredet. Det er holdepunkter for at stabiliteten av bindingen av rusmidler og metabolitter til komponenter i hår kan variere betydelig mellom individer (11). Biomarkøranalyser $i$ hår har et tidsvindu av størrelsesorden flere måneder (håret vokser ca. $1 \mathrm{~cm}$ per måned) til år etter siste rusmiddelinntak. Det er også holdepunkter for at separat hår- analyse av segmenter av for eksempel $1 \mathrm{~cm}$ lengde kan gi en brukbar grovhistorikk av personens rusmiddelbruk i perioden forut for prøvetakningen. I hvilken grad man kan anse slike segmentanalyser som representative for rusmiddelhistorikken, er foreløpig ikke godt nok kartlagt.

\section{Kombinasjonen av flere inntaksmarkører}

Som det fremgår dekker de forskjellige inntaksmarkørene forskjellige tidsvinduer $\mathrm{i}$ relasjon til rusmiddelinntaket. Ved å kombinere bruken av flere forskjellige metoder, for eksempel målinger av et rusmiddel/metabolitt i hår, urin og blod kan en få en viss innsikt i bruksmønsteret frem mot tidspunktet for prøveuttak til målingene. Dette kan i enkelte sammenhenger gi verdifulle opplysninger i epidemiologiske undersøkelser for eksempel mht. om det er langtidsbruk i tiden før, eller om det er et enkelt inntak som er viktigst for en målt klinisk tilstand.

\section{DEN IDEELLE MÅLING AV RUSMIDDEL- EKSPOSISJON}

Det fremgår av det overstående at bruken av biomarkører kan være til nytte for å kartlegge en rusmiddeleksposisjon. Det fremgår også at vi per i dag neppe kan få en god kartlegging av slik eksposisjon ved hjelp av biomarkører alene. Spørsmål om rusmiddelbruk er derfor viktige, selv om svarene ofte ikke er nøyaktige nok. Det er mange grunner til det siste, de to viktigste er kanskje for det første at bruk av de fleste rusmidler er ulovlig og at svarene influeres av dette, og for det andre at rusmiddelbruk generelt har en negativ effekt på hukommelsen, både under rus og etter langtidsbruk. I noen studier har man for alkohol forsøkt seg med dagbokføring av alt inntak i en periode. Faren ved en slik metode kan imidlertid være at målemetoden blir så vidt rigorøs at den påvirker det inntaket metoden skal måle.

Alt $\mathrm{i}$ alt betyr dette at behovet for objektive målinger av rusmiddeleksposisjon er stort. Mange muligheter synes fortsatt å være relativt beskjedent utforsket, og det vil være spennende å se om fremtiden vil kunne frembringe gode biomarkører i feltet.

\section{REFERANSER}

1. Grant BF, Stinson FS, Dawson DA, Chou SP, Dufour MC, Compton W, Pickering RP, Kaplan K. Prevalence and co-occurrence of substance use disorders and independent mood and anxiety disorders: results from the National Epidemiologic Survey on Alcohol and Related Conditions. Arch Gen Psychiatry 2004; 61: 807-816.

2. Huang SY, Lin WW, Ko HC, Lee JF, Wang TJ, Chou YH, Yin SJ, Lu RB. Possible interaction of ADH and ALDH genes with dopamine D2 reseptor (DRD2) gene in anxiety-depressive alcoholic dependence. Alcohol Clin Exp Res 2004; 28: 374-384.

3. Javors MA, Johnson BA. Current status of carbohydrate-deficient transferrin, total serum sialic acid, sialic acid index of apolipoprotein $\mathrm{J}$ and serum beta-hexosamidase as markers for alcohol comsumption. Addiction 2003; 98 (Suppl 2): 45-50. 
4. Beck O, Helander A. 5-hydroxytryptophol as a marker for recent alcohol intake. Addiction 2003; 98 (Suppl 2): 63-72.

5. Fagerberg B, Agewall S, Berglund A, Wysocki M, Lundberg PA, Lindstedt G. Is carbohydrate-deficient transferrin in serum useful for detecting excessive alcohol consumption in hypertensive patiens? Clin Chem 1994; 40: 2057-2063.

6. Bråthen G, Bjerve KS, Brodtkorb E, Helde G, Bovim G. Detection of alcohol abuse in neurological patiens: variables of clinical relevance to the accuracy of the \%-CDT-TIA and CDTect methods. Alcohol Clin Exp Res 2001; 25: 46-53.

7. Whitfield JB, Fletcher LM, Murphey TL, Powell LW, Halliday J, Heath AC, Martin PR. Smoking, obesity, and hypertension alter the dose-response curve and sensitivity of CDT as a marker of alcohol intake. Clin Chem 1998; 44: 2480-2489.

8. Sillanaukee P, Olsson U. Improved diagnostic classification of alcohol abusers by combining carbohydrate deficient transferrin and gamma-glutamyltransferase. Clin Chem 2001; 47: 681-685.

9. Peterson CM, Polizzi CM. Improved method for acetaldehyde in plasma and haemoglobin associated acetaldehyde: Results in teetotalers and alcoholics reporting for treatment. Alcohol 1987; 4: 477-480.

10. Wurst FM, Alexon S, Wolfersdorf M, Bechtel G, Forster S, Alling C, Aradottir S, Jachau K, Huber P, Allan JP, Auwärter V, Pragst F. Concentration of fatty acid ethyl esters in hair of alcoholics: Comparison to other biological state markers and self reported ethanol intake. Alcohol Alcohol 2004; 39: 33-38.

11. Pragst F. Pitfalls in hair analysis. Bull Int Assoc Forensic Toxicol 2005; 25: 10-17.

12. Peterson K. Biomarkers for alcohol use and abuse. Alcohol Res Health 2004/2005; 28: 30-37. 